http://doi.org/10.35784/iapgos.933

\title{
EXERGY-BASED CONTROL STRATEGY IN A DWELLING VENTILATION SYSTEM WITH HEAT RECOVERY
}

\author{
Volodymyr Voloshchuk, Mariya Polishchuk \\ National Technical University of Ukraine "Igor Sikorsky Kyiv Polytechnic Institute", Department of Automation of Thermal Processes, Kyiv, Ukraine
}

Abstract. The paper presents energy and exergy analysis of a typical dwelling ventilation system with heat recovery for Ukrainian climatic conditions using a quasi-steady state approach over 24-hour time-steps. Evaluation of such systems on the base of the first law of thermodynamics demonstrates that heat recovery is beneficial for the whole variety of operational modes. Such methodology identifies as a thermodynamic inefficiency only energy losses to the surroundings with the exhaust air. The exergy-based analysis can detect additional inefficiencies due to irreversibilities within the components of the system. As a result the exergetic investigations show that for the ventilation systems there are operating conditions for which heat recovery increases exergy of fuel expended to provide the ventilation air compared to cases without bringing any recovery of heat and additional power consumption to drive the air flow by the fans. For the specified system, in case of switching ventilation unit to the operation mode of lower values of spent fuel exergy it is possible to provide annual saving of the primary energy sources from 5 to $15 \%$.

Keywords: ventilation system, exergy analysis, control, heat recovery, exergy saving

\section{OPARTA NA EGZERGI STRATEGIA STEROWANIA SYSTEMEM WENTYLACJI MIESZKAŃ Z ODZYSKIEM CIEPLA}

\begin{abstract}
Streszczenie. W pracy przedstawiono analize energetyczna i egzergetyczna typowego systemu wentylacji mieszkań z odzyskiem ciepta dla ukraińskich warunków klimatycznych z zastosowaniem podejścia quasi-stabilnego w 24-godzinnych krokach czasowych. Ocena takich systemów w oparciu o pierwsze prawo termodynamiki wykazuje, że odzysk ciepła jest korzystny dla całego szeregu trybów pracy. Taka metodologia identyfikuje jako nieefektywne termodynamicznie tylko straty energii do otoczenia wraz z powietrzem wylotowym. Analiza egzergetyczna może wykryć dodatkowe nieefektywności wynikające z nieodwracalności elementów systemu. W rezultacie badania egzergetyczne wykazuja, że w systemach wentylacyjnych występuja warunki pracy, dla których odzysk ciepła zwiększa egzergię paliwa zużytego do dostarczenia powietrza wentylacyjnego w porównaniu do przypadków, w których nie występuje żaden odzysk ciepła i dodatkowe zużycie energii elektrycznej do napędzania przeptywu powietrza przez wentylatory. Dla określonego systemu, w przypadku przełaczenia urzadzenia wentylacyjnego na tryb pracy o niższych wartościach egzergii zużytego paliwa możliwe jest zapewnienie rocznych oszczędności pierwotnych źródet energii od 5 do $15 \%$.
\end{abstract}

Słowa kluczowe: system wentylacji, analiza egzergii, kontrola, odzysk ciepła, oszczędność egzergii

\section{Introduction}

Heat/energy recovery from exhaust air in dwelling ventilation systems provides a possibility to reduce energy consumption [4]. From viewpoint of the energy conservation statement which is based on the first law of thermodynamics such systems are effective. Due to recovery of heat from the exhausted stream heat losses to the environment are decreased. These are the only detectable energy losses (i.e., inefficiencies) in an energy analysis. The main drawback of this evaluation is that it fails to provide the full information about the real thermodynamic inefficiencies in a system.

Exergy-based methods reveal the location, magnitude of thermodynamic inefficiencies and the effects that cause them. As a results exergetic techniques can be successfully applied in evaluating the potential for improving the efficiency of the system.

Over the last two decades special attention is being paid to the so called low exergy (LowEx) heating and cooling systems [2]. LowEx systems are defined as systems that allow the use of low valued energy as the energy source. Such strategy provides matching the quality of supplied energy with the demand. This implicitly accounts thermodynamic inefficiencies in the given system. The application of exergy-based methods in buildings to identify and reduce this quality mismatch has aroused great interest among some scientists in recent years [2].

In a dwelling ventilation system with heat recovery to drive fans for air distribution electricity is consumed. The quality of electrical energy is much higher compared with the same amount of recovered thermal energy. Exergy-based approach which is based on the second law of thermodynamics provides a possibility to evaluate the level of energy quality and improve control of dwelling ventilation system by decreasing consumption of the most valuable types of energy.

The paper [8] presents steady-state energy and exergy analyses for dwelling ventilation with and without air-to-air heat recovery and discusses the relative influence of heat and electricity on the exergy demand by ventilation airflows in winter conditions of Netherlands. It has been shown that from an exergy viewpoint, it could make sense to use the heat recovery unit only when environmental air temperature is low enough to compensate the additional need for electricity. When the air temperature is not too low, electricity input could be decreased by letting ventilation air bypass the heat recovery unit or by operating the heat recovery unit at low ventilation airflow rate, depending on outdoor temperatures and indoor occupancy conditions.

The authors [5] in contrast to traditional performance parameters also applied exergy analysis and nonequilibrium thermodynamics to characterize the performance of heat recovery ventilator and a structurally similar membrane energy recovery one. They showed that the exergy efficiency can be used to identify the range of operating conditions for which the recovered heat and moisture are not enough to compensate power consumed by ventilation fans, and for which it is more beneficial to bypass the energy recovery unit.

The work [1] addresses the trade-off of heat recovery and fan power consumption in the ventilation system based on primary energy, carbon dioxide emission, household consumer energy price and exergy frameworks for a broad range of operating conditions in the different climates in Europe. The paper shows that the profitability concerning operating energy recovery ventilation as opposed to simple mechanical exhaust or natural ventilation strongly depends on the type of conversion coefficient between electrical energy and fuel combustion for heating, building performance, climatic conditions of a region, investment and maintenance cost.

On the annual energy and exergy performance the paper [3] shows that addition of a mechanical ventilation system with heat recovery increases the energy efficiency, however, it decreases the exergy efficiency. The authors conclude that the use of a separate mechanical ventilation system in a house should be considered with caution, and recommended only when other means for controlling the indoor air quality cannot be applied.

The results presented in considered papers are based on the exergy values at room or primary energy levels without focusing on the efficiency of energy conversion and delivery processes steps. The conclusions may be more sophisticated and practical if the exergy-based parameters are considered in all subsystems of energy conversion system which provides a possibility to identify 
and calculate the location, magnitude and causes of thermodynamic inefficiencies in an energy conversion system.

The scope of the paper is to demonstrate benefits of application of exergy-based approach for better control strategy in a dwelling ventilation system taking into account all intermediate steps from primary energy transformation to final energy consumption in climate conditions of Ukraine.

\section{Methodology}

The Figure 1 provides a schematic illustration of the analyzed system from primary energy conversion to the building envelope The dwelling ventilation system consists of a heat recovery unit, two fans and two additional heaters. In case of heat recovery from the exhausted air stream the system increases the electricity consumption by ventilation fans to compensate additional pressure drops in the air-to-air heat exchanger. If the outdoor air temperature is too low the ventilation air is first preheated with the additional hot water preheater. The second hot water heater is used only if the temperature of ventilation air, after the heat recovery, is lower than the indoor air temperature. If streams bypass the recovery unit the outdoor air is heated in the both hot water heaters and fan power required to drive the air flow is decreased.

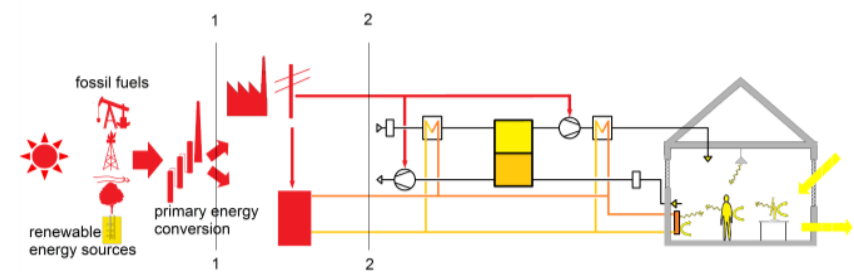

Fig. 1. Energy supply chain for space heating in a buildings from primary energy transformation to final energy, including all intermediate steps up to the supply of the heating demand

Two control layers are considered to analyze the amount of fuel exergy (representing the resources in terms of exergy) expended to provide the product exergy (representing the desired result, ventilation air, in terms of exergy) [6] (see Figure 1).

For investigation of variable operational modes of the system due to fluctuating in outdoor conditions a mathematical model for energy and exergy assesment has been developed using 24-hour time step quasi-stationary approach. The model is based on mass, energy and exergy balances for the specified dwelling, ventilation and heating system.

The analysis is performed for a typical Ukrainian individual house. The dwelling has one floor with a gross floor area of $90 \mathrm{~m}^{2}$ and a volume of $225 \mathrm{~m}^{3}$. For the reference case weighted average insulation value of non-glazed external surfaces is $0.5 \mathrm{~W} /\left(\mathrm{m}^{2} \cdot \mathrm{K}\right)$. U-value of windows including frames is $2 \mathrm{~W} /\left(\mathrm{m}^{2} \cdot \mathrm{K}\right)$. Infiltration rate is regarded as $1 \mathrm{~h}^{-1}$. Internal heat gains are defined with a constant value of $10 \mathrm{~W} / \mathrm{m}^{2}$ [10]. Setpoint for the indoor temperature is $18^{\circ} \mathrm{C}$. The fraction of east and west oriented glazing is $30 \%$, of the south one $-50 \%$, of the north one $-20 \%$. Heat recovery efficiency of the ventilation system is equal $55 \%$. Heating needs in the both hot water heaters are covered by a heat pump system. Low temperature energy utilised in the evaporator of the heat pump is not taken into account in calculations.

For the control layer 2 the exergy of fuel is calculated using the formula

$$
E_{F, 2}(\tau)=E_{F, P H}(\tau)+E_{F, H}(\tau)+E_{F, \text { fun }}(\tau)
$$

where

$$
\begin{aligned}
& E_{F, P H}(\tau)=E n_{P H}(\tau) \cdot\left\{1-\frac{T_{0}(\tau)}{T_{\text {in }}(\tau)-T_{\text {out }}(\tau)} \ln \left(\frac{T_{\text {in }}(\tau)}{T_{\text {out }}(\tau)}\right)\right\} \\
& E_{F, P H}(\tau)=\operatorname{En}_{H}(\tau) \cdot\left\{1-\frac{T_{0}(\tau)}{T_{\text {in }}(\tau)-T_{\text {out }}(\tau)} \ln \left(\frac{T_{\text {in }}(\tau)}{T_{\text {out }}(\tau)}\right)\right\}
\end{aligned}
$$

$\tau$ - time step, $\tau=24 \mathrm{hr} ; E n_{P H}, E n_{H}$ - daily energy consumed in the hot water preheater and heater of the ventilation air, $\mathrm{kW} \cdot \mathrm{h}$;
$T_{0}$ - temperature of outside air, $\mathrm{K} ; T_{\text {in }}$ - heater and preheater inlet temperature of water, $\mathrm{K} ; T_{\text {out }}$ - heater and preheater outlet temperature of water, $\mathrm{K} ; E_{F, f u n}$ - electricity consumed by the fans, $\mathrm{kW} \cdot \mathrm{h}$.

For the control layer 1 representing the primary energy inlet the exergy of fuel is calculated using the formula

$$
E_{F, 1}(\tau)=\frac{E_{F, H P}(\tau)+E_{F, \text { fun }}(\tau)}{\varepsilon}
$$

where

$$
E_{F, H P}(\tau)=\frac{E n_{P H}(\tau)+E n_{H}(\tau)}{C O P(\tau)}
$$

$\varepsilon$ - exergy efficiency of electricity generation on thermal power plant, $\varepsilon=0.37$ [9]; $\operatorname{COP}(\tau)-$ coefficient of performance of the heat pump system, calculated on the base of [7].

The values of $C O P$ are highly dependent on the temperature difference between the source and sink. Because of variation of operational conditions within building the calculated $C O P$ values varied within the range from 2.5 to 4.5 .

Primary energy sources are based on fossil fuels [2]. For simplicity the quality factors of different kinds of fossil fuels are equal to 1.0 .

\section{Results and discussions}

Figure 2 presents the results of application the energy balance approach for the calculations of consumed energy for providing ventilation air within the range of outside temperatures $-20 \ldots 14^{\circ} \mathrm{C}$. In this case the control layer 2 is considered.

It is clearly observed that for the analysed layer heat recovery from ventilation airflow plays an increasingly important role in minimising energy needs. According to the obtained results energy consumed for providing ventilation air with recovering heat from the exhausted air (line 1) is lower compared to cases without energy recovering (line 2) for the investigated variety of outside temperatures. But it should be noted that the energy analysis identifies only an energy transport to the surroundings as a thermodynamic inefficiency. Such approach does not provide information about all existing thermodynamic inefficiencies within the system. The necessary data can be obtained on the base of exergy analysis.

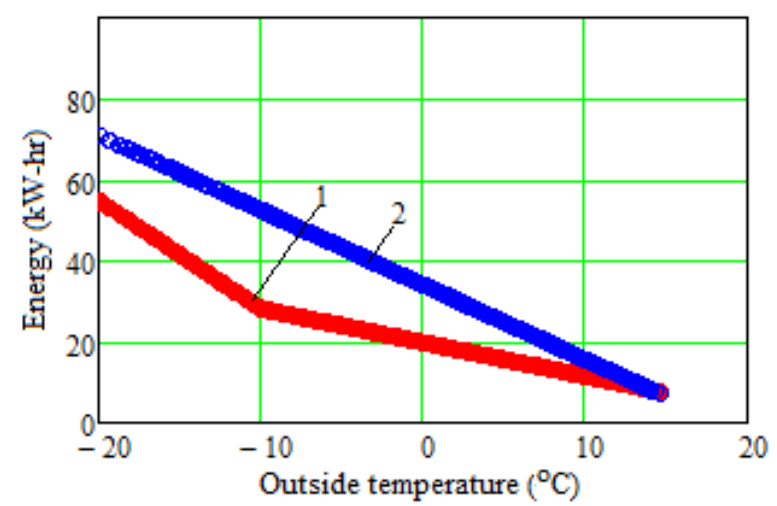

Fig. 2. Energy consumed for providing ventilation air versus outside temperature for the control layer 2: 1-with heat recovery; 2-without heat recovery

Figure 3 illustrates values of the exergy of fuel expended to provide the ventilation air for the control layer 2 as a function of outside temperature. The line 1 represents the mode of using heat recovery system. The line 2 belongs to the mode when the air streams bypass the recovery unit. It can be observed that the lines 1 and 2 intersect at the environmental air temperature equal to $-6^{\circ} \mathrm{C}$. For this temperature the values of exergy of fuel for the two different modes are equal. So, at the environmental air temperatures lower than $-6^{\circ} \mathrm{C}$ the exergy of fuel expended to provide the ventilation air is lower for the mode 1 (heat recovery application). If the outside air temperatures are higher than $-6^{\circ} \mathrm{C}$ it is more beneficial to bypass the recovery unit. 


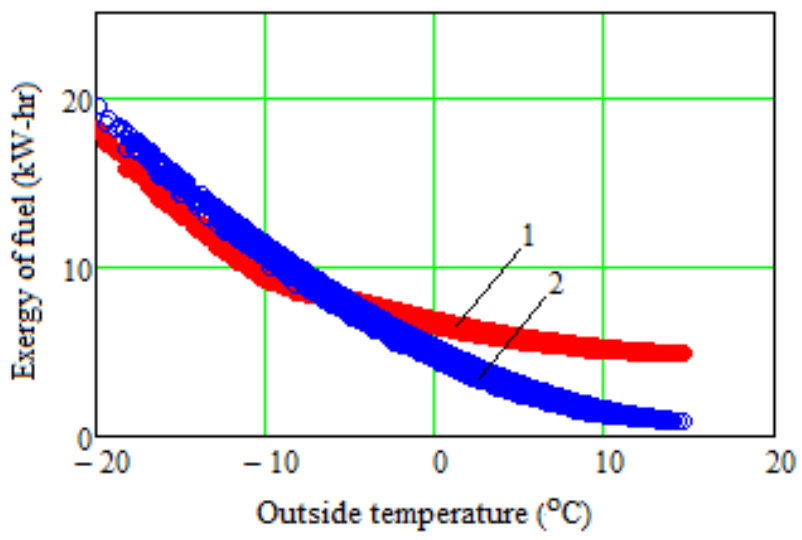

Fig. 3. Exergy of fuel expended to provide the ventilation air versus outside temperature for the control layer 2: 1 -with heat recovery; 2 - without heat recovery

Figure 4 presents results of calculating values of the exergy of fuel spent in the ventilation system as a function of outside air temperature for the control layer 1 which is associated with primary energy sources inlet. The line 1 belongs to the mode of heat recovery and the line 2 - to the mode of bypassing the recovery unit. For the control layer 1, if the outside air temperatures are lower than $0^{\circ} \mathrm{C}$ the exergy associated with fuel is lower for the mode 1 (heat recovery application). On the contrary, if the outside temperatures are higher than $0^{\circ} \mathrm{C}$ it is makes sense to bypass the recovery unit because the exergy of fuel for this mode is lower than for the mode of heat recovery.

Taking into account that the quality factors of different kinds of fossil fuels is equal to 1.0 it can be concluded that energy spent in providing ventilation air for the control layer 1 is the same as the spent fuel exergy.

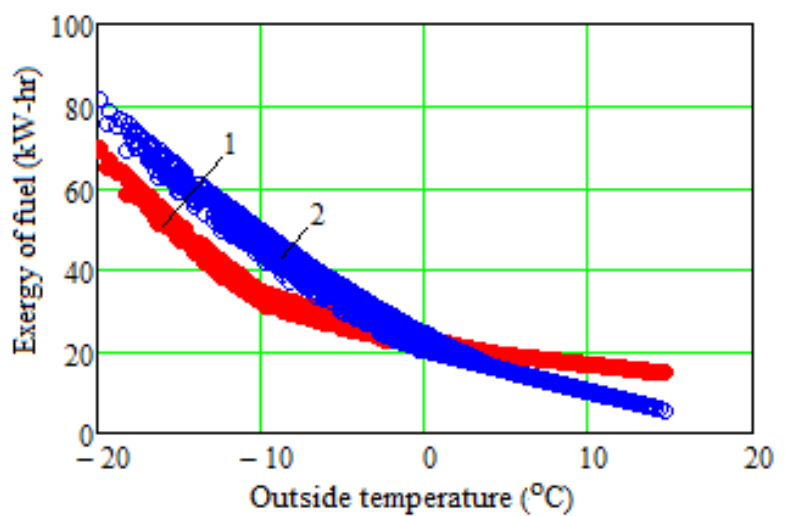

Fig. 4. Exergy of fuel expended to provide the ventilation air versus outside temperature for the control layer 1: 1-with heat recovery; 2 - without heat recovery

Energy and exergy flows from the primary energy sources to the indoor ventilation air through the entire dwelling ventilation system are illustrated in Figures 5 and 6 . These results are presented for the outdoor temperature $10^{\circ} \mathrm{C}$ and $-10^{\circ} \mathrm{C}$ respectively. The diagrams clearly show advantages of the exergy analysis as compared with the energy one. From the primary energy inlet (layer 1) to the indoor ventilation air the value of exergy flow is decreased due to thermodynamic inefficiencies. And the steps with the biggest decrease of exergy can be identified. The energy approach does not provide such information.

In case of the outdoor temperature equal to $10^{\circ} \mathrm{C}$ higher exergy destruction $(19 \mathrm{~kW} \cdot \mathrm{h}-5 \mathrm{~kW} \cdot \mathrm{h}=14 \mathrm{~kW} \cdot \mathrm{h})$ belong to the system with heat recovery in the step of energy conversion between the layers 1 and 2. But during energy conversion from the layer 2 to the indoor ventilation air exergy destruction is also quite high and equal to $5 \mathrm{~kW} \cdot \mathrm{h}-0.2 \mathrm{~kW} \cdot \mathrm{h} \approx 5 \mathrm{~kW} \cdot \mathrm{h}$. For the system without recovering energy from the exhaust air (bypassing mode) exergy destructions are lower for the both energy conversion steps and this mode is more beneficial.
If the outdoor temperature is equal to $-10^{\circ} \mathrm{C}$ (see Figure 6) it is more efficient to use heat recovery. For this operational mode within the both energy conversion steps (from the layer 1 to layer the 2 and from the layer 2 to the indoor ventilation air) exergy destructions are equal to 27 and $7 \mathrm{~kW} \cdot \mathrm{h}$ respectively which is lower compared with the case of bypassing the recovery unit.

In case of applying energetic analysis it is quite difficult to identify the more efficient mode since it is impossible to detect any thermodynamic inefficiencies in the system.

For example, as can be seen from Figure 5 for the outdoor temperature $10^{\circ} \mathrm{C}$, in case of using heat recovery (dashed line 1), for the layer 2 inlet energy flow is equal $12 \mathrm{~kW} \cdot \mathrm{h}$ but the outlet one representing indoor ventilation air is equal to $15 \mathrm{~kW} \cdot \mathrm{h}$. The increase of $3 \mathrm{~kW} \cdot \mathrm{h}$ of energy is due to recovered heat from the exhaust air. But if heat recovering is not used (dashed line 2) $1 \mathrm{~kW} \cdot \mathrm{h}$ of energy losses are observed. So, using energetic approach the investigator can make a wrong conclusion about applying heat recovery. But, as a result, for such operational mode the primary energy consumption will be equal to $19 \mathrm{~kW} \cdot \mathrm{h}$ which is higher by $8 \mathrm{~kW} \cdot \mathrm{h}$ compared with the mode of bypassing the recovery unit.

So, only the exergy analysis can provide correct information which can be used to find improvement potentials for operational modes.

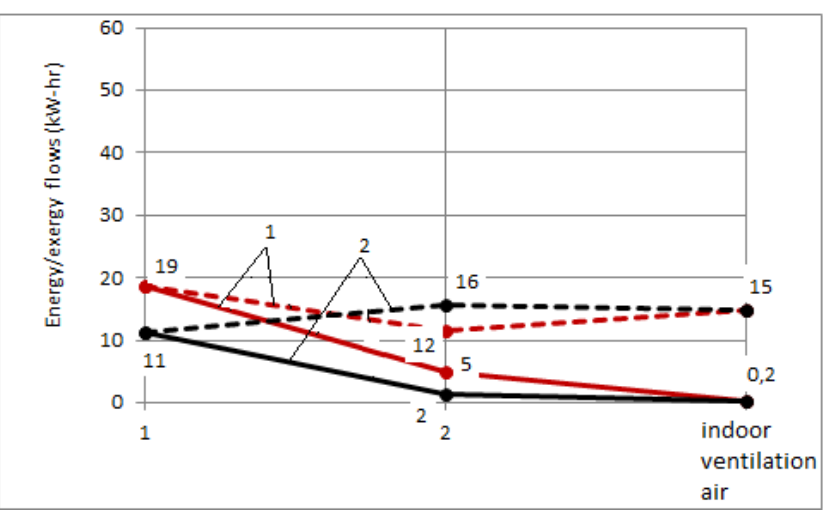

Fig. 5. Energy and exergy flows of the dwelling ventilation system from the primary energy source to the indoor ventilation air for outside air temperature $10^{\circ} \mathrm{C}: 1-$ with heat recovery; 2 - without heat recovery; solid lines - exergy flows, dashed lines energy flows

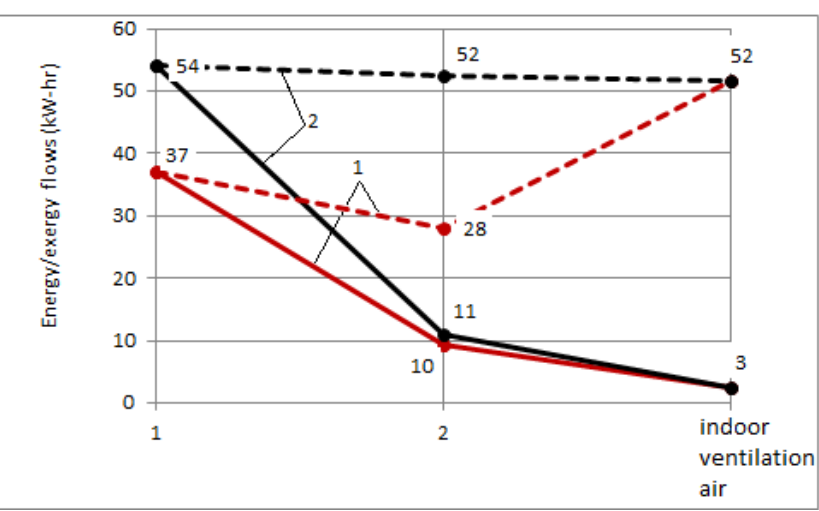

Fig. 6. Energy and exergy flows of the dwelling ventilation system from the primary energy source to the indoor ventilation air for outside air temperature $-10^{\circ} \mathrm{C}$ : 1 - with heat recovery; 2 - without heat recovery; solid lines - exergy flows, dashed lines - energy flows

For the more detailed analysis of the causes of thermodynamic inefficiencies from the layer 2 to the indoor ventilation air of the investigated system the differentiated values of exergy flows of the dwelling ventilation system for outside air temperature $10^{\circ} \mathrm{C}$ are presented in Figure 7. It can be clearly observed that in comparison to the case of bypassing the recovery unit ventilation with heat recovering demonstrates higher thermodynamic inefficiency due to irreversibilities associated with the fan power consumed to drive the air flow through the recovery system. 


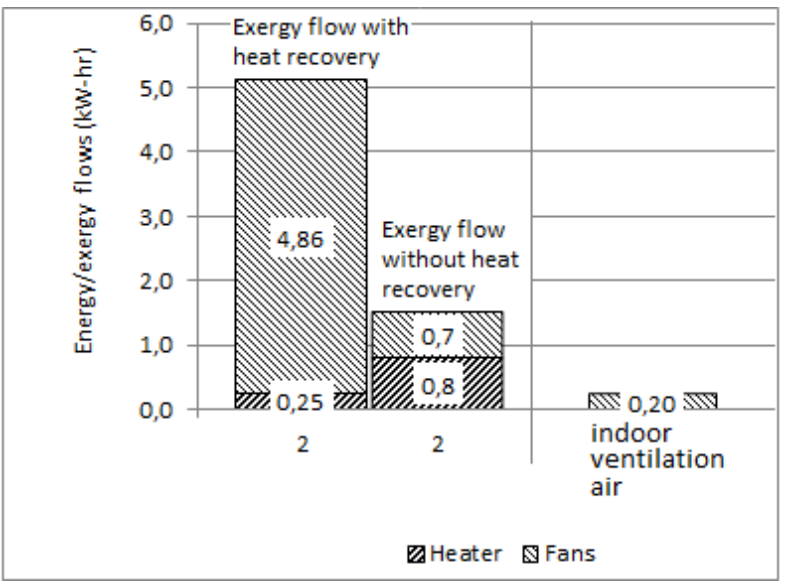

Fig. 7. Differentiated exergy flows of the dwelling ventilation system from the layer 2 to the indoor ventilation air for outside air temperature $10^{\circ} \mathrm{C}$

The results presented above reveal a potential to improve the efficiency of the dwelling ventilation system through the implementation of an exergy-based control strategy, which tries to fulfill the demand of the ventilation system with low-quality energy sources involving the bypassing mode of heat recovery unit. The results of such strategy are presented in Figure 8 for the layer 1 which demonstrates the primary energy sources consumption.

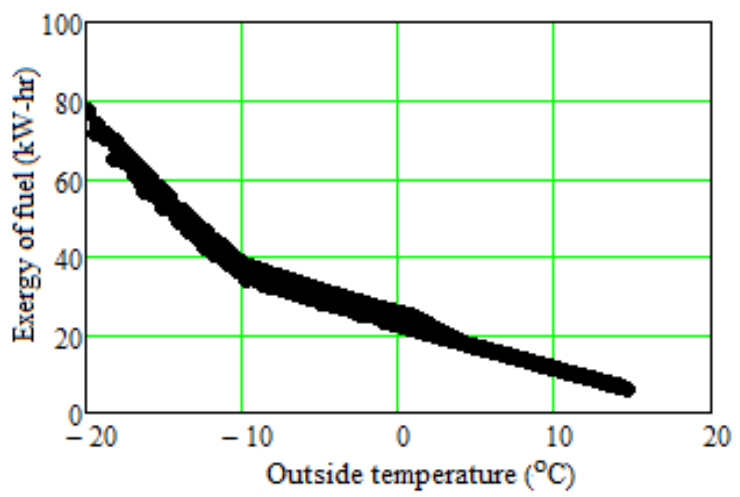

Fig. 8. Exergy of fuel expended to provide the ventilation air versus outside temperature for the control layer 1 through the implementation of the exergy-based control strategy

Figure 9 demonstrates the values of annual fuel exergy saving over 27-year period for the control layer 1 (primary energy sources) of the reference system in case of applying the proposed exergy-based control approach.

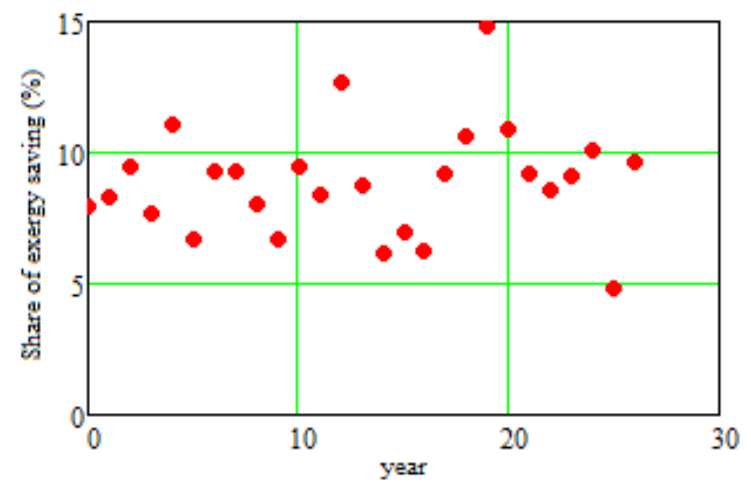

Fig. 9. Annual values of saving exergy associated with fuel for the control layer 1

It can be observed from Figure 9 that in comparison to the conventional operating dwelling ventilation system with heat recovery (recovering energy from the exhausted air stream for the all range of operating modes) it is possible to save annually from 5 to $15 \%$ of the primary high quality energy by bypassing the recovery unit in cases when the recovered exergy of heat is not enough to compensate the fan power consumed to drive the air flow through the recovery unit.

\section{Conclusions}

The present paper proposes the exergy-based optimal control strategy the identifying the range of operating conditions within which the dwelling ventilation system with heat recovery consumes more the high-quality energy sources (electricity) compared to the conditions for which bypassing the recovery unit is applied. Detailed explanation of the necessity of such strategy application is provided.

For the climate conditions and typical buildings of Ukraine it has been found that implementation of the proposed exergy-based control strategy provides a possibility of saving annually from 5 to $15 \%$ of the primary high quality energy sources.

\section{References}

[1] Gjennestad M.Aa., Aursand E., Magnanelli E., Pharoah J.: Performance analysis of heat and energy recovery ventilators using exergy analysis and nonequilibrium thermodynamics. Energy and Buildings 170, 2018, 195-205.

[2] Hepbasli A.: Low exergy (LowEx) heating and cooling systems for sustainable buildings and societies. Renewable and Sustainable Energy Reviews 16(1), 2012, 73-104.

[3] Jensen J.K., Ommen T., Reinholdt L., Markussen W.B., Elmegaard B.: Heat pump COP, part 2: Generalized COP estimation of heat pump processes. Proceedings of the 13th IIR-Gustav Lorentzen Conference on Natural Refrigerants 2, 2018, 1136-1145.

[4] Laverge J., Janssens A.: Heat recovery ventilation operation traded off against natural and simple exhaust ventilation in Europe by primary energy factor, carbon dioxide emission, household consumer price and exergy. Energy and Buildings 50, 2012, 315-323.

[5] Mert Cuce P., Riffat S.: A comprehensive review of heat recovery systems for building applications. Renewable and Sustainable Energy Reviews 47, 2015, 665-682.

[6] Rosen M.A., Dincer I. Effect of varying dead-state properties on energy and exergy analyses of thermal systems. International Journal of Thermal Sciences 43, 2004, 121-133.

[7] Sakulpipatsin P., Boelman E., Cauberg J.J.M.: Exergy analysis as an assessment tool of heat recovery of dwelling ventilation systems. Int. J. of Ventilation 6(1), 2007, 77-85.

[8] Tsatsaronis G.: Definitions and nomenclature in exergy analysis and exergoeconomics. Energy 32, 2007, 249-253.

[9] Zmeureanu R., Wu X.Y.: Energy and exergy performance of residential heating systems with separate mechanical ventilation, Energy 32(3), 2007, 187-195.

[10] National Standard of Ukraine: Instruction for development of energy passport of buildings under new construction and reconstruction: DSTU-N B A.2.2-5:2007. Minregionbud of Ukraine, Kiev 2008.

\section{Prof. Volodymyr Voloshchuk}

e-mail: Vl.Volodya@gmail.com

He is a professor of the department of automation of thermal processes in National Technical University of Ukraine "Igor Sikorsky Kyiv Polytechnic Institute". The scientific activity is devoted to development and implementation of mathematical and computer modeling of thermal processes, exergy-based design, assessment, optimization and control of thermal systems.

http://orcid.org/0000-0003-0687-8968

M.Sc. Mariya Polishchuk

e-mail: atep_mariya@ukr.net

She is a Ph.D. student of the department of automation of thermal processes in National Technical University of Ukraine "Igor Sikorsky Kyiv Polytechnic Institute". The research interests lie in the field of mathematical and computer modeling of thermal processes and control theory.

http://orcid.org/0000-0003-2273-3750

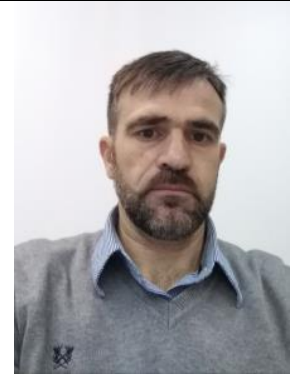

otrzymano/received: 22.12 .2019 